\title{
Evaluation of asphalt binder blended with coconut coir dust and residual coconut fibers for structural applications
}

\author{
Evaluación de asfalto mezclado con polvo de corteza y fibras residuales de coco para \\ aplicaciones estructurales
}

\author{
Alexandra Loaiza (Main Author) \\ Laboratorio CCComposites, Facultad de Ingeniería, Universidad de Antioquía-UdeA \\ Calle 70 No. 52-21, Medellín, (Colombia) \\ I.I.alexandra88@gmail.com
}

\section{Edwin Garcia}

Departamento de Ingeniería Civil, Universidad de Antioquía-UdeA

Medellín (Colombia)

edwin.garcia@udea.edu.co

Henry A. Colorado (Corresponding Author)

Laboratorio CCComposites, Facultad de Ingeniería, Universidad de Antioquía-UdeA

Calle 70 No. 52-21, Medellín (Colombia)

Henry.colorado@udea.edu.co

Manuscript Code: 1143

Date of Acceptance/Reception: 01.12.2018/24.16.2018

DOI: 10.7764/RDLC.17.3.542

\begin{abstract}
This is an investigation into asphalt binder mixed with different amounts of an organic waste containing coconut coir dust and residual short coconut fibers abundant in the Caribbean and tropical countries. The concentrations used were 0.0, 1.0, 2.5 and 5.0wt\%. Coconut coir is a type of organic waste produced in large quantities in Caribbean region of Colombia. It is composed of grinded mesocarp, which is the fibrous husk of the coconut fruit, and is currently used in agriculture, ornaments and crafts. This waste is a very stable and strong material suitable for use in structural applications such as the reinforcement of composite materials. In this investigation, materials characterization was conducted using Fourier transform infrared spectroscopy and scanning electron microscopy to analyze the microstructure of samples. Particle size distribution tests were also included to analyze the short coconut fibers. Penetration, softening point, penetration index, viscosity, flash point, fire point and ductility performance tests were also carried out on the asphalt mixes. Overall, these tests revealed that asphalt formulations can be used in selected construction and building material applications.
\end{abstract}

Keywords: Asphalt, coconut fibers, composite materials, infrastructure, natural fibers.

\section{Resumen}

Esta es una investigación sobre asfalto mezclado con diferentes cantidades de un residuo orgánico de polvo de corteza y fibras residuales de coco muy abundante en países del Caribe y del Trópico. Se han fabricado muestras con 0.0, 1.0, 2.5 y 5.0\% en peso del residuo. Este residuo es un tipo de residuo orgánico producido en grandes cantidades en la región caribe de Colombia. Se compone del mesocarpio molido, el cual se encuentra en la corteza fibrosa del coco, y es actualmente usado en agricultura, adornos y artesanías. Este residuo es un material muy estable y resistente, además de versátil para su uso en aplicaciones estructurales tales como refuerzo en materiales compuestos. En este trabajo, la caracterización de los materiales se realizó mediante espectroscopía infrarroja por transformada de Fourier y por microscopía electrónica de barrido, con el fin de analizar la microestructura de las muestras. También se realizaron ensayos de distribución de tamaño de las fibras cortas. Adicionalmente, también se realizaron sobre las mezclas asfálticas ensayos de penetración, punto de ablandamiento, índice de penetración, viscosidad, punto de inflamación, punto de llama y ductilidad. En general, estos ensayos revelaron que las formulaciones de asfalto pueden ser usadas en infraestructura bajo esfuerzos no críticos.

Asphalt is a highly viscous material produced by the distillation of petroleum residues (Herráiz, Herráiz, Domingo, \& Domingo, 2016) and is used in combination with very diverse solid materials which act as reinforcers, fillers and additives. These solid materials include different aggregates (Collis \& Smith, 1993), or they can be other reinforcers such as fiber wastes (Abtahi, Sheikhzadeh, \& Hejazi, 2010; Colorado \& Loaiza, 2017) (Y. Huang, Bird, \& Heidrich, 2007; Mallick, Teto, \& Mogawer, 2000) and additives (Abdullah, Zamhari, Shamshudin, Mohd Rosli, \& Idham, 2013; Colorado, Nino, \& Restrepo, 2018; Sengoz \& Oylumluoglu, 2013). Therefore, asphalt binders and concrete are excellent systems to act as test materials for new applications. Around 70wt\% asphalt is commonly used in road 
pavement construction, due to its well-known binder and waterproofing properties (Vale, Casagrande, \& Soares, 2013). Nevertheless, this material, as supplied, is hugely susceptible to high temperatures (Marasteanu, Clyne, McGraw, Li, \& Velasquez, 2005) and to drain-down (Putman \& Amirkhanian, 2004). Therefore, asphalt needs to be modified before being used in building and infrastructure applications (Alexandra Loaiza, Cifuentes, \& Colorado, 2017; Mohd Adlo Sani, Latib, Ng, Yusof, Ahmad, \& Rani, 2011).

Asphalt modifiers can be classified according to their purposes in the mix. They can stiffen the binder at high temperatures to decrease rutting problems (Brown \& Cross, 1989), soften binders to improve strain tolerances at low temperatures (Yildirim, 2007), and improve fatigue resistance (Lee, Rust, Hamouda, Kim, \& Borden, 2005), among many other abilities (King, King, Pavlovich, Epps, \& Kandhal, 1999). These modifiers can also be fillers, fibers, polymers, elastomers, wastes and/or combinations of these (Sani et al., 2011). In recent years, using wastes as modifiers in asphalt has received more attention because it could decrease the amount of waste in landfills and, at the same time, reduce the costs of engineering products (A. Loaiza, Cifuentes, \& Colorado, 2017; Mallick, Teto, Mogawer 2000; Wu, Ye, \& Li, 2008).

In addition, fibers have recently been used in asphalt mixtures due to their proven benefits. Both natural and synthetic fibers have been utilized, such as basalt and jute as natural fibers (Davar, Tanzadeh, \& Fadaee, 2017; GAO \& WU, 2017; T. Herráiz, et al., 2016; Mansourian, Razmi, \& Razavi, 2016; Zhang, Gu, Lv, Zhu, \& Zou, 2017), and steel, polymers and glass as synthetic fibers (Amuchi, Abtahi, Koosha, Hejazi, \& Sheikhzeinoddin, 2015; Ge, Wang, Zhang, \& Xiong, 2015; Guo, Li, Cheng, Jiao, \& Xu, 2015; Morova, Serin, Terzi, Saltan, Ozdemir, Sargin \& Eriskin, 2016; Pamulapati, Elseifi, Cooper, Mohammad, \& Elbagalati, 2017; Park, El-Tawil, \& Naaman, 2017; Yang, Kim, \& Yoo, 2016). For instance, kenaf fibers were used to improve the Marshall stability of ordinary Hot Mix Asphalt (HMA) (Sani et al., 2011). Posidonia Oceanica fiber, which is an algae fiber, has been shown to provide improved stiffness in asphalt mixtures when the fiber content is between $1.5 \%$ and $2 \%$ (Herráiz et al., 2016). Moreover, it has been demonstrated that a chemical bond exists between fibers and asphalt (GAO \& WU, 2017). Using other natural reinforcements in asphalt, such as coconut coir and fibers, has been explored very little. The benefits of coconut fibers as reinforcement materials have been shown in diverse structural materials and applications such as roofs (Castañeda, Argüello, \& Vecchia, 2010) although this involves a more complex material as binder, which limits its application to infrastructure.

Coconut is a very common food and plant in tropical areas such as Colombia, Sri Lanka, the Philippines and Indonesia (Evans, Konduru, \& Stamps, 1996). It consists of the white meat (28wt\%), hard shell (12wt\%) and the husk (35wt\%). Coconut coir dust is the product that remains after the long fibers have been extracted from the coir, which is the outer part of the coconut. This byproduct consists of short to medium length fibers and dust. The long fibers of coconut coir are used in the production of ropes, mattress padding and brushes, and constitute $30 \%$ of the coir, while the remaining $70 \%$ consists of coir dust (van Dam, van den Oever, Teunissen, Keijsers, \& Peralta, 2004). These particulate materials are typically used for agricultural proposes, such as a material to fertilize the soil, increase the porosity of the soil and retain water. However, a large amount of this waste is incinerated without any control of gas emissions, and it therefore constitutes a source of contamination (Abad, Noguera, Puchades, Maquieira, \& Noguera, 2002). Annually, there are about 40 to 50 million tons of coconuts produced around the world, which means the amount of coir dust generated is 10 to 12 million tons (Ohler, 1984). Coir dust mainly consists of hemicellulose (29.5wt\%), lignin (24.1wt\%) and $\alpha$-cellulose (21.0\%) (van Dam, et al., 2004). It has a highly porous structure and has a low susceptibility to biodegradation, which makes it suitable for holding huge quantities of water (more than $50 \%$ by weight) (Ohler, 1984). In the Caribbean region of Colombia, these materials are produced extensively and are considered as waste. Thus, any use of them on a large scale would be a great opportunity for industry because of their low costs. They are also an environmentally friendly solution and represent a potential community integration project for locals in the Caribbean zones of many countries. Recently, up to $1.5 \mathrm{wt} \%$ coir dust has been used in asphalt mixtures and its effect has been evaluated in the Marshall stability tests (Hadiwardoyo, 2013; Panda, Suchismita, \& Giri, 2013). The addition of 0.75 wt\% showed an increase of $10-15 \%$ in the Marshall stability of the samples fabricated.

The present study assesses the use of up to $5.0 \mathrm{wt} \%$ coconut coir in asphalt cement. Considering that compositions with more than $1.5 \mathrm{wt} \%$ of coconut coir have not been previously evaluated, the current results are unique and would appeal to many applications in the construction and infrastructure sector (Kumar, Kumar, Laxmi, \& Birru, n.d.; Su, Qiu, Schlangen, \& Wang, 2015). The fibers were characterized by SEM microscopy and FTIR tests. The mixtures were evaluated by penetration, softening point, viscosity, ductility, fire point and flash point. The mail goal of this research is to attempt to decrease the pollution caused by coconut coir dust and to improve the properties of a material that has potential use in engineering. In addition, this research aims to find new uses for coconut derived wastes and offer an innovative alternative for local Caribbean communities who can use them in technical applications such as composites and building materials. Asphalt binder blended with coconut coir dust and residual coconut fibers could become an environmental and economic alternative to improve soils and make flexible pavements in road 
construction. The use of these natural fibers could also be a way to create cultural and economic networks in areas that need to make alternative housing using their own materials.

\section{Description of the problem}

As established in the previous introduction and state of the art, coconut coir dust and residual coconut fibers have several applications but not enough to be considered out of the waste materials, particularly in the tropical areas, which remains for long time because the material is quite resistant to environmental conditions. Since about 10 to 12 million tons (Ohler, 1984) of this waste is mostly unused worldwide, this waste is an important material to consider particularly because the main problem is located in places such as some regions of Latin-America and the Caribbean. Therefore, it is necessary to seek for massive solutions easily implemented by the locals, and therefore make a contribution to the environment, the community, and the economy of the involved places. Thus, the solution presented in this research not only involves inexpensive materials and processing, but also the fabrication can be conducted by anyone from individuals to companies.

Methodology

Grade 60-70 asphalt was supplied by the Colombian national oil company, Ecopetrol, and its properties are summarized in Table 1. Coconut coir dust with some residual fibers were obtained from a local market in Colombia. They were a mixture of coconut pith or coconut dust composed of powder with some short coconut fibers (less than 2 $\mathrm{mm}$ ), see Table 2 iError! No se encuentra el origen de la referencia..

\begin{tabular}{|c|c|c|c|c|}
\hline Test & Units & Result & Other information & Methods \\
\hline 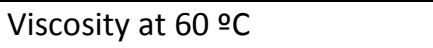 & $\mathrm{cP}$ & 242000 & & ASTM D 4402 \\
\hline Viscosity at 80 ㅇ C & $\mathrm{CP}$ & 21750 & & ASTM D 4402 \\
\hline 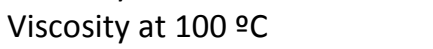 & $\mathrm{CP}$ & 3725 & & ASTM D 4402 \\
\hline Viscosity at $135 \circ \mathrm{C}$ & $\mathrm{cP}$ & 395 & & ASTM D 4402 \\
\hline 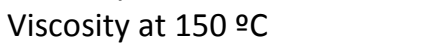 & $\mathrm{CP}$ & 217.5 & & ASTM D 4402 \\
\hline Ductility & $\mathrm{cm}$ & 140 & $\geq 100$ & Asfalto VENT \\
\hline Gravity API & Grados API & 6.9 & & ASTM D 4052 \\
\hline Density at $15 \stackrel{\circ}{ } \mathrm{C}$ & $\mathrm{Kg} / \mathrm{m}^{3}$ & 1021.7 & & ASTM D 4052 \\
\hline Penetration at $25 \circ \mathrm{C}$ & $\mathrm{mm} / 10$ & 60 & $60-70$ & Asfalto VENT \\
\hline Penetration index & N/A & -1 & & Asfalto VENT \\
\hline Mass loss (RTFO) & $\mathrm{g} / 100 \mathrm{~g}$ & 0.48 & $\leq 1.0$ & Asfalto VENT \\
\hline Softening point & oc & 49.2 & $45-55$ & Asfalto VENT \\
\hline Flame point & $\underline{\circ} \mathrm{C}$ & 294 & $\geq 232$ & ASTM \\
\hline Solubility in trichloroethylene & $\%$ & 99.7 & $\geq 99.0$ & Asfalt VENT \\
\hline
\end{tabular}

\begin{tabular}{|c|c|c|}
\hline Characteristics & Value & Units \\
\hline Total organic carbon & 20.30 & $\%$ \\
\hline Humidity & 0.30 & $\%$ \\
\hline Ashes & 2.68 & $\%$ \\
\hline $\mathrm{pH}$ in saturated paste & 4.78 & N/A \\
\hline Density & 0.09 & $\mathrm{~g} / \mathrm{cm}^{3}$ \\
\hline Moisture retention capacity & 198.83 & $\%$ \\
\hline
\end{tabular}

Figure 1a shows the parts of a coconut fruit. The internal endosperm is the white solid eatable flesh which contains the drinkable liquid. The fruit is covered by the endocarp, which is a hard-coated inner shell. The mesocarp covers the endocarp with a voluminous fibrous husk, which is the main material used in this investigation. Upon processing the coconut coir in a grinding machine, a particulate like-waste material is obtained, as shown in Figure 1b, composed of powder and some short fibers. 

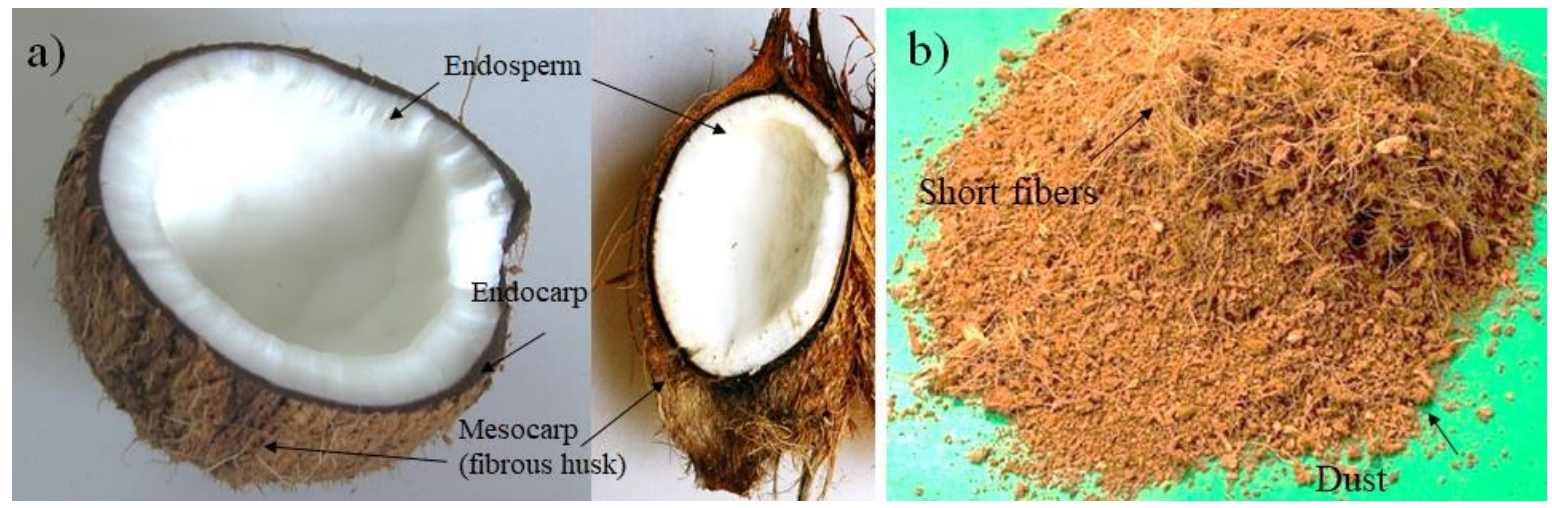

The properties of these short fibers have been investigated and are described in Table 3. Asphalt was mixed with 0.0 (neat asphalt), 1.0, 2.5 and 5.0wt\% of coconut fibers. The mixing process was conducted in a Velp Scientifica mechanical stirrer for 1 hour at $155 \stackrel{\circ}{\circ}$ and at $200 \mathrm{rpm}$ in order to guarantee a good distribution of the waste in the asphalt binder.

Table 3. Short coconut fiber properties.

\begin{tabular}{|c|c|c|c|}
\hline Property & Value & Units & Reference \\
\hline Tensile strength & 220 & $\mathrm{MPa}$ & (Wambua, Ivens, \& Verpoest, 2003) \\
\hline Young's Modulus & 6 & GPa & (Wambua et al, 2003) \\
\hline $\begin{array}{l}\text { Elongation at } \\
\text { break }\end{array}$ & $15-25$ & $\%$ & (Wambua et al., 2003) \\
\hline Flexural strength & 29226 & $\mathrm{MPa}$ & $\begin{array}{c}\text { (Harish, Michael, Bensely, Lal, \& } \\
\text { Rajadurai, 2009) }\end{array}$ \\
\hline Impact strength & 11 & $\mathrm{KJ} / \mathrm{m}^{2}$ & (Harish et al., 2009) \\
\hline
\end{tabular}

For the SEM-EDS examinations, the samples were mounted on an aluminum stub and sputtered in a Hummer 6.2 system (15mA AC for $30 \mathrm{sec}$ ) creating a $1 \mathrm{~nm}$ thick film of gold. The SEM was a JEOL JSM 6490LV used in high vacuum mode. The particle size distribution was obtained from the analysis of the SEM images using Image-J software. Before the grinding process, the coconut fibers were cryogenically treated in liquid nitrogen and then broken, which allowed a clean cross-sectional view to be obtained. After the grinding process, the coconut coir waste was observed in the SEM without further treatment. For the composite, since the particulate waste was inside the bulk, the samples were also submerged in liquid nitrogen and then broken in order to show the fiber distribution.

Penetration tests were conducted following the ASTM D5 standard at $25 \stackrel{\circ}{\circ}$ using a control penetrometer. Softening point tests were made following the ASTM D36 standard in a ring and ball apparatus. The viscosity test was carried out in a rotational Brookfield viscometer at $60{ }^{\circ} \mathrm{C}$ to assess the high temperature workability before and after adding the waste. The ductility test was performed in a control ductilimeter according to the ASTM D113-07 standard test method for examining the ductility of bituminous materials. Flash and fire points were tested according to the Cleveland open cup method and the ASTM D92 standard. The penetration index was calculated using the corresponding equation and the penetration and softening point results (Pfeiffer \& Van Doormaal, 1936). FTIR spectra were obtained for the coconut fibers in a Shimadzu apparatus with wave numbers ranging from 500 to $3500 \mathrm{~cm}^{-1}$. Potassium bromide $(\mathrm{KBr})$ powder was used in this research. In most cases, curve fits were included as a reference to show the trends, mostly because they can be easily read and used by engineers in industry.

\section{Results and discussion}

Figure 2 shows SEM microscopy images for the coconut husk before the grinding process. Figure 2a shows that fibers are typically 100 to $300 \mu \mathrm{m}$ in diameter and very porous, which is common to many natural fibers (Neves Monteiro, Salgado de Assis, Ferreira, Tonini Simonassi, Pondé Weber, Souza Oliveira, Colorado \& Camposo Pereira, 2018). This means they can be used in a positive way for applications such as those needing water retention (Raghavendra, Swamy, Rastogi, Raghavarao, Kumar \& Tharanathan, 2006) and low density composites (Teles, Altoé, Amoy, Netto, Colorado, Margem \& Monteiro, 2015). Figure 2b, reveals details of the porous structure, with some semi-hexagonal 
tubes of about $10 \mu \mathrm{m}$ diameter. Figure $2 \mathrm{c}$ and Figure $2 \mathrm{~d}$ show the coir dust particles which were used as received, with their shape and surface affected by the grinding process. Figure 3 summarizes the diameter distribution of the coconut coir dust, with diameters averaging $204 \pm 81 \mu \mathrm{m}$ and ranging from 50 to $300 \mu \mathrm{m}$. The diameter distribution of coconut fibers was also studied by (Fernandes, Correlo, Mano, \& Reis, 2013) who reported a mean value of $277.4 \mu \mathrm{m}$, and a range of $71.8-465.6 \mu \mathrm{m}$.
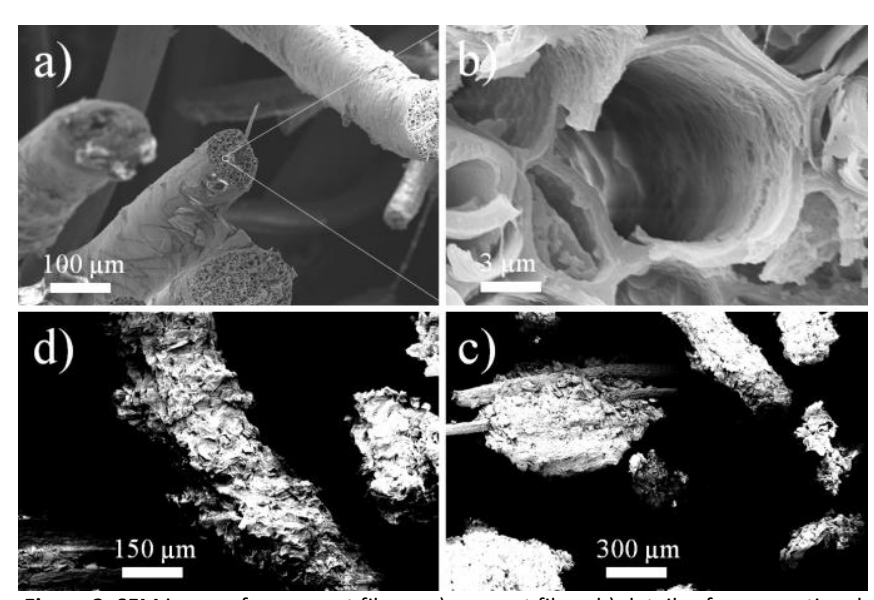

Figure 2. SEM images for coconut fibers, a) coconut fiber, b) details of cross sectional view of a fiber, c) and d) coconut coir dust.

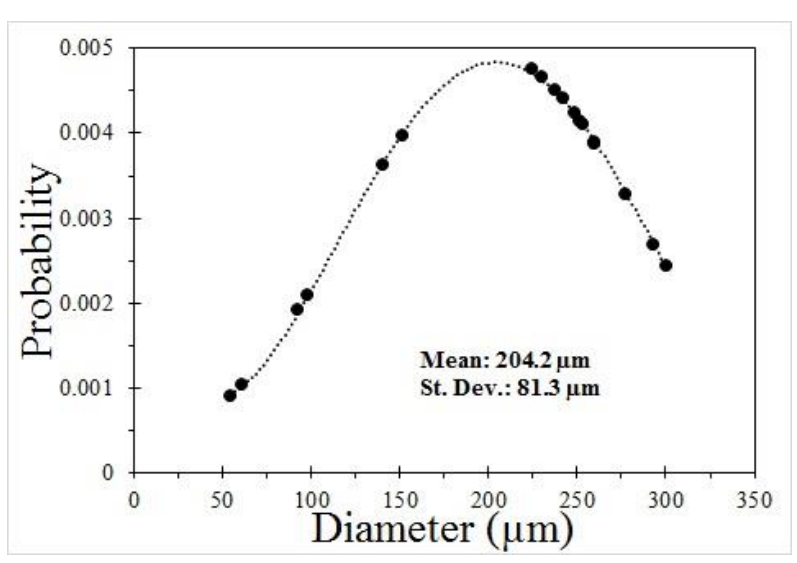

Figure 3. Particle size distribution of the coconut coir dust used.

Figure 4a shows the penetration, softening point (Figure $4 \mathrm{~b}$ ) and penetration index results (Figure 4c). The linear trend and other subsequent curves were included as a reference for easy observation. The penetration index (PI) was found with equation 1 (Pfeiffer \& Van Doormaal, 1936), and the corresponding results are shown in Figure 4c, where $P$ is the penetration and SP is the softening point.

$$
P I=\frac{1952-500 *(P)-20 * S P}{50 * \log (P)-S P-120}
$$

The results showed that the penetration decreased by $32.4 \%$ for $5 \mathrm{wt} \%$ coir dust. The softening point decreased and then increased at $5.0 \mathrm{wt} \%$. The penetration index showed the same behavior as the softening point. PI gives an idea of the temperature susceptibility of the fabricated mixtures: if PI is below -2 , the mixture is highly temperature susceptible, as summarized in Table 4. None of the mixtures fabricated in the present investigation showed a penetration index over -2 , which means they were all highly temperature susceptible.

\begin{tabular}{lc} 
Table 4. Typical values of PI in asphalt cement.(Radovskiy \& Teltayev, 2018). \\
\hline Asphalt type & $\begin{array}{c}\text { Penetration } \\
\text { Index }\end{array}$ \\
\hline Blown asphalt & $>2$ \\
$\begin{array}{l}\text { Conventional asphalt road } \\
\text { pavement }\end{array}$ & -2 to +2 \\
Temperature susceptible asphalt & $<2$ \\
\hline
\end{tabular}


Figure 4. Different characterization tests for samples with different contents of coconut coir dust: a) penetration, b) softening point, c) penetration index. Source: own.

a)

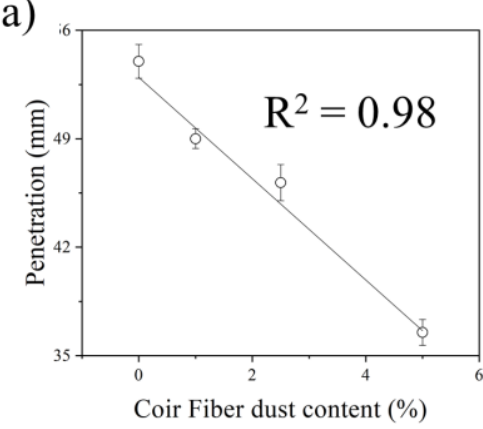

c)

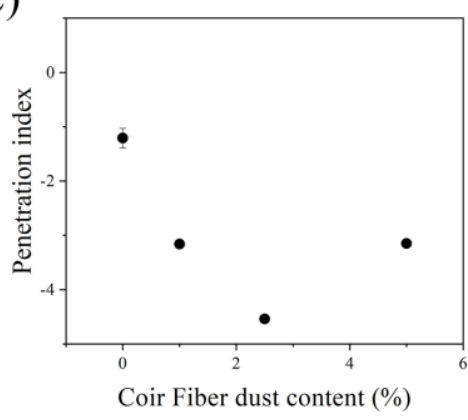

b)

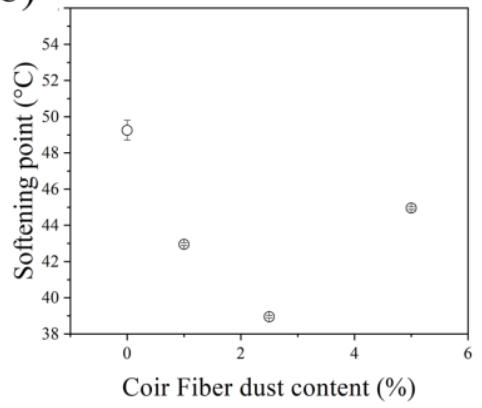

Figure 5 shows the results for viscosity, ductility, flash point and fire point for the coir waste mixed with asphalt binder. Figure 5a shows that viscosity increased as more coir dust was added, while ductility shows the opposite behavior to viscosity, as can be seen in Figure $5 \mathrm{~b}$. The ductility was $32.5 \mathrm{~cm}$ for samples with the highest coir dust content, which corresponds to a reduction of $79.4 \%$. The flash point test also showed an increase in ductility when the amount of coir dust increased, as shown in Figure 5c. The fire point presented more complex behavior as it first increased, then decreased, and then increased again when the coconut coir dust was added (Figure 5d). This could be due to the coconut coir not burning in the mixing process and being partially and non-homogeneously altered.

Figure 6 shows SEM images for asphalt mixed with coconut coir dust, with a) $1 w t \%$, b) $2.5 w t \%$, and c) $5 w t \%$ of coconut coir dust. In general, the binder fully impregnated the coconut waste. Also, the waste was found to be approximately distributed homogenously. The complex shapes that appear in the images correspond to asphalt deformed after the breaking process.

Figure 5. Different characterization tests for samples with different contents of coconut coir dust: a) viscosity, b) ductility, c) flash point, d) fire point. Source: own.

a)

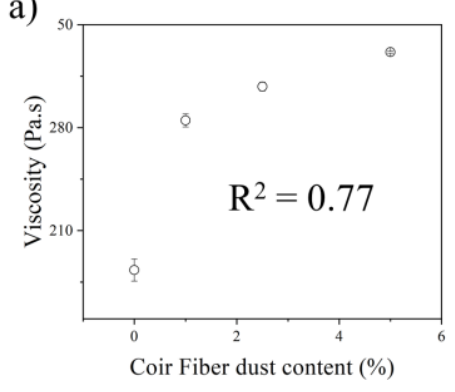

c)

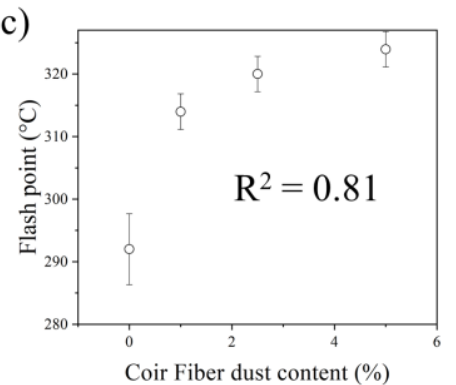

b)

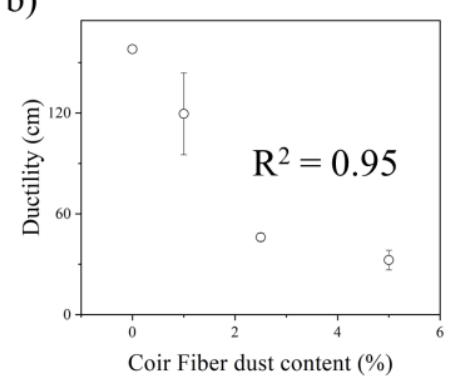

d)

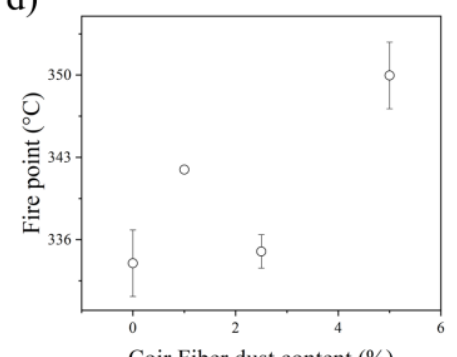

Coir Fiber dust content (\%) 
The FTIR spectrum presented in Figure 6 revealed the presence of structural characteristics for lignin which correspond to coconut and, in general, to other natural fiber structures. The strong bands seen from $2900-3400 \mathrm{~cm}^{-1}$ are attributed to stretching vibrations of hydroxyl groups, including the absorbing of water and symmetric and asymmetric $\mathrm{C}-\mathrm{H}$ stretches in the $\mathrm{CH}_{3}, \mathrm{CH}_{2}$ and $\mathrm{CH}$ groups. The band at $1645.2 \mathrm{~cm}^{-1}$ is assigned to the stretching vibrations of the $\mathrm{C}=\mathrm{O}$ functional groups. The band at $1246 \mathrm{~cm}^{-1}$ is related to $\mathrm{C}-\mathrm{OH}$ and $\mathrm{C}-\mathrm{O}$ stretches in $\mathrm{OCH}_{3}$. The band at 1041.5 corresponds to the $\mathrm{O}-\mathrm{CH}_{3}$ stretch and aromatic $\mathrm{CH}$ in plane bending. All of the bands were assigned according to the literature (Gnedenkov, Opra \& Zemnukhova, 2015).

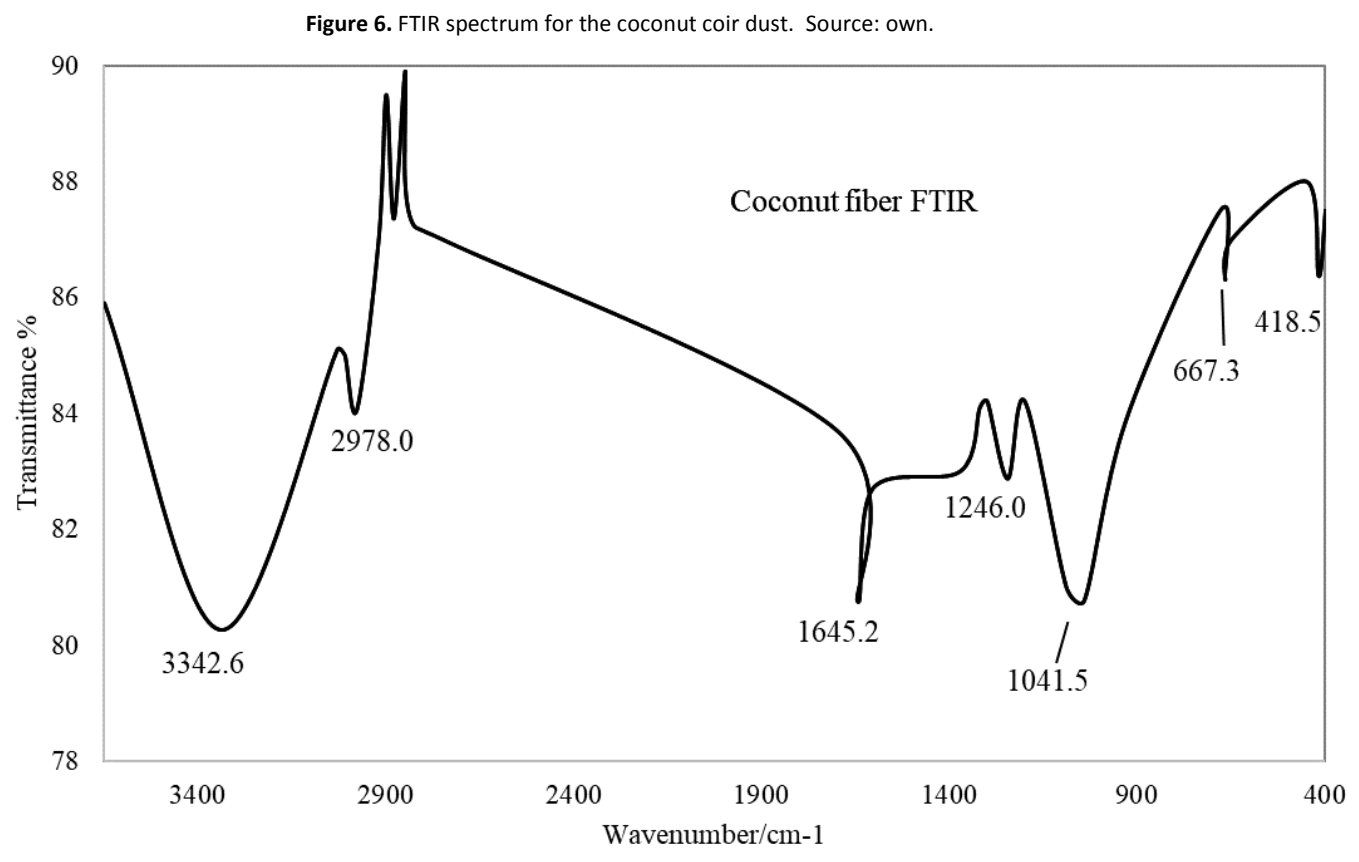

Discussion

The properties of asphalt when coconut coir dust is added will depend on several factors. The fiber surface, cellulose content, diameter, length, alignment, shape, fiber orientation, swelling effect, and amount of fiber are the main considerations in the properties of the composite material. The bonding of the fiber to the matrix is also one of the main concerns. Generally, the surface of the fibers is treated chemically (using NaOH) (Li, Tabil, \& Panigrahi, 2007; Prasad, Gowda, \& Velmurugan, 2017) or physically (by oxidation of the fibers) (Bismarck, Kumru, Song, Springer, Moos \& Karger-Kocsis, 1999; Parandoush \& Lin, 2017), in order to increase the roughness of the fiber. In turn, this increases adhesion between the fiber and the matrix as the adhesion is often poor (Bismarck et al., 1999; Li, Tabil \& Panigrahi, 2007; Parandoush \& Lin, 2017; Prasad et al., 2017). However, it was shown in this research that the fibers were fully impregnated by the asphalt matrix, and therefore no treatment was needed to guarantee the fiber-matrix adhesion.

The penetration of asphalt is an indirect measurement of the toughness of the material, which means that an asphalt with less penetration is harder than others with more penetration (Alsheyab \& Khedaywi, 2013; Alexandra Loaiza et al., 2017). Many mechanisms can act together to affect the toughness of an asphalt matrix mixed with coconut coir dust fibers, although one is predominant (Matthews \& Rawlings, 1999). When the fibers are pulled out of the matrix, creating a new higher energy surface, the stress is then transferred from the matrix to the fibers. The fibers can then withstand more stress than a polymeric matrix (Friedrich, 2012; "Microstructure, flexural properties and durability of coir fibre reinforced concrete beams externally strengthened with flax FRP composites," 2015; Silva, Spinelli, Bose Filho, Claro Neto, Chierice \& Tarpani, 2006). However, there is a maximum or optimum value in which mechanical properties are at their best. Due to the low density of coconut fibers, they become a continuous phase at low weight percentages, as fibers in composite material are responsible for load carrying elements and providing strength and rigidity. The matrix is responsible for maintaining the fibers in alignment. When the optimum quantity of fibers is reached, they no longer accomplish their main function (Arpitha \& Yogesha, 2017).

The penetration results show that, as the fiber content increases, the penetration of the bitumen decreases, thereby indicating a surge in the viscosity of the mixture. This rise in viscosity suggests that the stiffness of the mixture increases and in turn its deformation capacity under load conditions decreases. The increase in viscosity shown in Figure 5 a suggests there is a brittleness effect when the fibers are added to the asphalt. The viscosity is higher, 
possibly due to an entanglement effect caused by the fibers. The ductility seen in Figure $5 b$ supports the idea of a structure that reinforces the asphalt matrix since it becomes less ductile as the content of coconut fibers increases. These changes make the asphalt more resistant to deformations (Chen \& Lin, 2005). Unlike many other construction materials, bitumen is a viscoelastic material which exhibits both viscous and elastic characteristics when undergoing deformation. The stiffness modulus describes the mechanical properties of bitumen. The concept, introduced in 1954 by Van der Poel, is the ratio of stress $(\sigma)$ to strain $(\varepsilon)$. However, the properties of a viscous material depend on loading time and temperature (Athanassios, 2015; V. Poel \& Der, 1954; Read, Whiteoak, \& Bitumen, 2003; C. Van der Poel, 1954). Thus, the stiffness modulus at a given temperature $(T)$ and loading time $(t)$ is determined by Equation 2 (Athanassios, 2015).

$$
\left(S_{b i t}\right)_{t, T}=\sigma / \varepsilon_{t, T}
$$

The stiffness modulus is calculated by the Van der Poel nomograph, which is given by a loading time of $0.02 \mathrm{~s}$, a temperature of $25^{\circ} \mathrm{C}$, the softening point and the penetration index (Athanassios, 2015; Y. H. Huang, 1993; Read et al., 2003). Figure 7a shows the Van der Poel nomograph and Figure $7 \mathrm{~b}$ shows the behavior of stiffness according to different fiber contents. The stiffness modulus prediction shows constant behavior up to $2.5 \mathrm{wt} \%$ of coconut fibers. At $2.5 \mathrm{wt} \%$ the stiffness modulus increases to $80 \mathrm{MPa}$ and then decreases to $20 \mathrm{MPa}$.

Figure 7. a) Van Der Poel nomograph, b) Stiffness modulus calculated from Van Der Poel nomograph. Source: own.

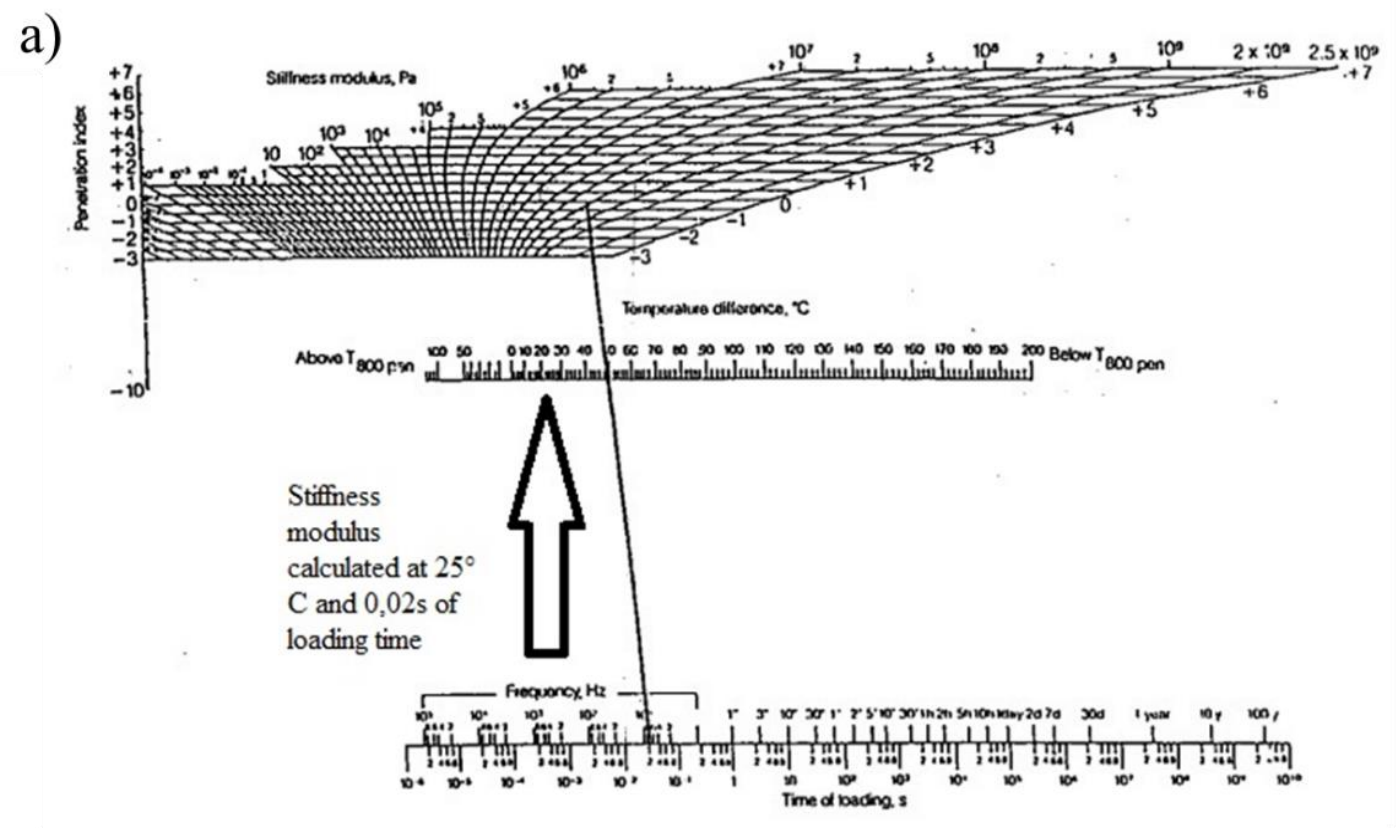

b)

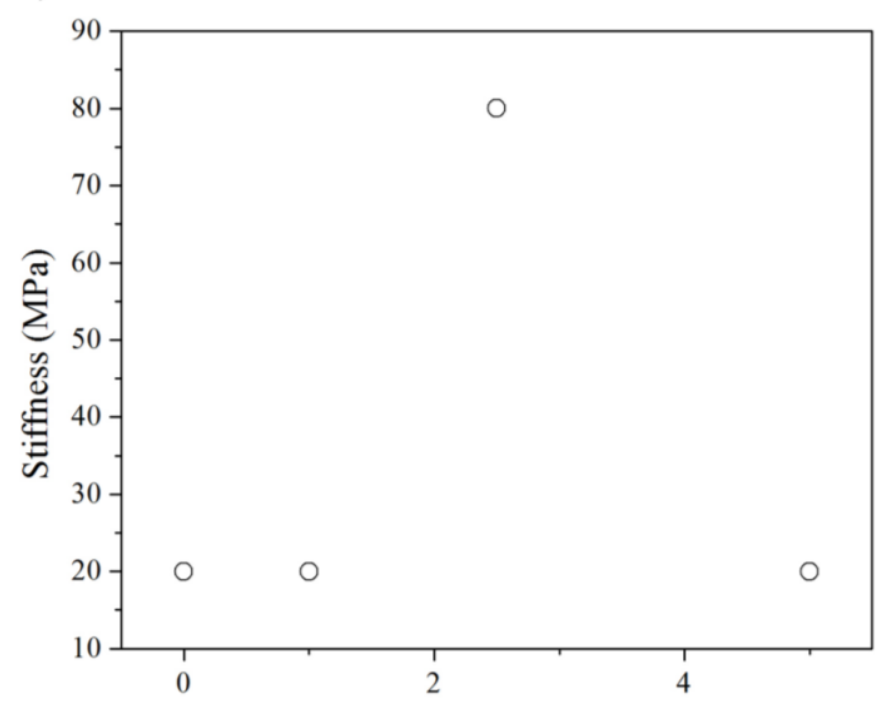

Coir Fiber dust content (\%) 
Figure 8. a) Heukelom nomograph, b) Strain of break calculated from Heukelom nomograph. Source: own.

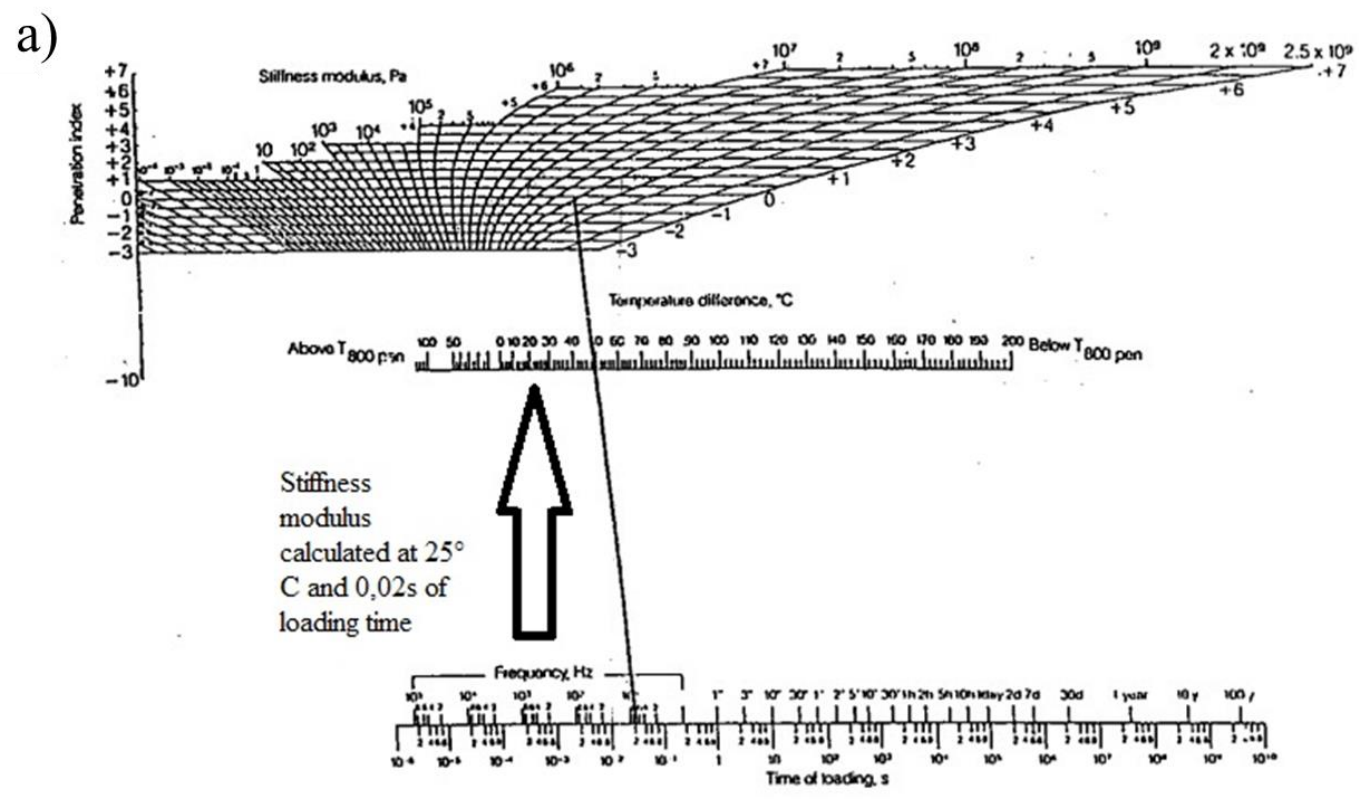

b)

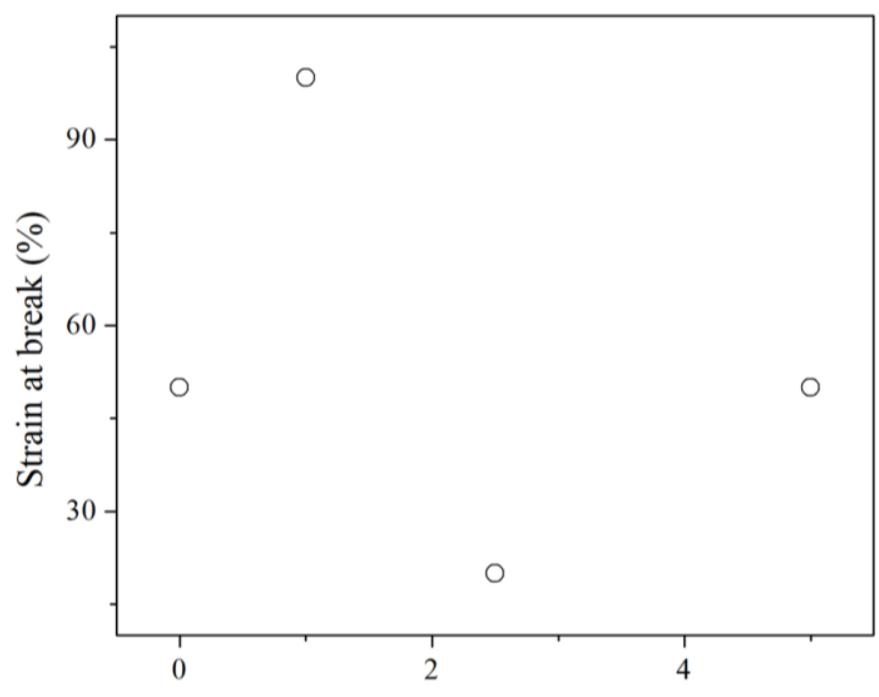

Coir Fiber dust content (\%)

The strain at break can be also predicted by the Heukelom nomograph, in this case evaluated at $0.02 \mathrm{~s}$ loading time and $25^{\circ} \mathrm{C}$ in temperature. Figure $8 \mathrm{a}$ shows the Hewkelom nomograph and Figure $8 \mathrm{~b}$ shows the behavior of the strain at break with increasing coconut fiber content. A small strain at break is associated with both a high stiffness and brittleness. A high strain at break is associated with materials that do not fracture easily but that could deform (Athanassios, 2015; Bitumen, 1995; Read et al., 2003). The strain at break presents very variable behavior. It increases at $1.0 \mathrm{wt} \%$, then it decreases at $2.5 \mathrm{wt} \%$. Therefore, it increases at the same value as the base asphalt $(0.0 \mathrm{wt} \%)$. This behavior could be explained due to the low density of coconut fibers. As they have a very high volume, the maximum or optimum is reached with a small amount of fibers.

Cracking in asphalt binders is one of the most significant and costly problems in cold climates around the world. The problem arises because, at low temperatures, tensile stresses are induced in the asphalt layers, resulting in the cracking of the mixture (Jung \& Vinson, 1994). Cracking can occur due to the contraction of the base and subbase layers and is associated with freezing processes, contraction of bituminous surfaces due to temperature change, or repetitive cycles of increase and decrease in temperature. Considering the importance of the temperature effect on the cracking of road structures, asphalt mixtures with fibers could be a good solution to counteract temperature stress as they increase the tensile strength of the mixtures. 
The results found in this research show a positive change in the deformation properties of the asphalt binder blended with coconut coir dust and residual coconut fibers. This offers significant and helpful insight into the cracking control of such mixtures when they are used for the improvement of soils and granular layers of roads and bituminous surfaces. Overall, the construction and building sector is one of the most polluting activities in the world because its processes generate a lot of waste, such as dust and residues of bricks, tiles, concrete and pavement. The sector is especially bad for the environment when it uses no renewable resources. Mining exploration is also a very polluting activity. The aim of this research is to develop an asphaltic material modified with coconut fibers to enhance the properties of asphalt for different uses. Organic fibers are cheaper than synthetic fibers and have many advantages, such as low density, less machine wear during processing, no health hazards, and a high degree of flexibility compared to organic fibers (Arpitha \& Yogesha, 2017). In addition, the use of these fibers is an environmental way to reduce waste. It can also be an alternative source of income for the many poor communities that rely on coconuts to earn a living, such as equatorial countries in Latin America and the Caribbean. However, there are some disadvantages of using these fibers to reinforce other materials. Among the disadvantages is the high variability in all properties, including strength and size. This is mainly due to the different conditions where the coconut grows, and results in fibers with different properties.

In this study, up to 5.0 wt\% of coconut fibers was mixed with asphalt. These fibers had a density of $0.09 \mathrm{~g} / \mathrm{cm}^{3}$, and thus, 1 ton of asphalt would easily hold $50 \mathrm{~kg}$ of coconut fibers, which corresponds to about $0.55 \mathrm{~m}^{3}$ of coconut fibers by volume. Just for reference, about 185 tons of asphalt cement are used in the construction of a road that is $1 \mathrm{~km}$ long, $7 \mathrm{~m}$ wide and $20 \mathrm{~cm}$ thick (Alexandra Loaiza \& Colorado, 2018). Therefore, the amount of coconut fibers which could be added to that road corresponds to $9250 \mathrm{~kg}$. Using this amount of asphalt binder is not only more competitive in terms of cost, but is also more environmentally friendly as asphalt is a non-renewable oil product processed at high temperature. The method used here could be applied to other waste based on natural fibers that has good mechanical and thermal stability (such as fique and pineapple fibers). In specific areas where natural waste is a problem, these fibers could be well-used as alternative materials.

\section{Conclusions}

In this study, asphalt was modified with coconut coir dust using a mechanical stirring process. The mixtures were assessed mechanically and micro-structurally. Up to $5 \mathrm{wt} \%$ fibers was added to asphalt so that the behavior of the mixture could be studied.

According to the mechanical results, there is a maximum or optimum value of coconut dust content which gives the best mechanical properties. If this content is exceeded, the properties change and the mixtures are weakened.

This study has provided an environmentally friendly alternative for waste generated when extracting coconut fibers. It is also an opportunity for coastal regions in many countries to develop their construction sector with alternative materials. The fibers could be employed in non-critical structural applications such as roofing and waterproofing. Coconut coir is not a hazardous waste, and this study proposes it be used for alternative applications rather than only in agriculture.

\section{Acknowledgements}

The authors wish to thank the engineer Sergio Cifuentes from Conasfaltos S.A., Colombia, for kindly supporting part of this project.

Abad, M., Noguera, P., Puchades, R., Maquieira, A., \& Noguera, V. (2002). Physico-chemical and chemical properties of some coconut coir dusts for use as a peat substitute for containerised ornamental plants. Bioresource Technology, 82(3), 241-245. https://doi.org/https://doi.org/10.1016/S0960-8524(01)00189-4

Abdullah, M. E., Zamhari, K. A., Shamshudin, M. K., Mohd Rosli, H., \& Idham, M. K. (2013). Rheological properties of asphalt binder modified with chemical warm asphalt additive. In Advanced Materials Research (Vol. 671, pp. 1692-1699). Trans. Tech. Publ.

Abtahi, S. M., Sheikhzadeh, M., \& Hejazi, S. M. (2010). Fiber-reinforced asphalt-concrete-a review. Construction and Building Materials, 24(6), 871877.

Alsheyab, M. A. T., \& Khedaywi, T. S. (2013). Effect of electric arc furnace dust (EAFD) on properties of asphalt cement mixture. Resources, Conservation and Recycling, 70, 38-43. https://doi.org/10.1016/j.resconrec.2012.10.003 
Amuchi, M., Abtahi, S. M., Koosha, B., Hejazi, S. M., \& Sheikhzeinoddin, H. (2015). Reinforcement of steel-slag asphalt concrete using polypropylene fibers. Journal of Industrial Textiles, 44(4), 526-541. Retrieved from 10.1177/1528083713502998

Arpitha, G. R., \& Yogesha, B. (2017). An overview on mechanical property evaluation of natural fiber reinforced polymers. Materials Today: Proceedings, 4(2), 2755-2760.

Athanassios, N. (2015). Highway Engineering: Pavements, Materials and Control of Quality. CRC Press.

Bismarck, A., Kumru, M. E., Song, B., Springer, J., Moos, E., \& Karger-Kocsis, J. (1999). Study on surface and mechanical fiber characteristics and their effect on the adhesion properties to a polycarbonate matrix tuned by anodic carbon fiber oxidation. Composites Part A: Applied Science and Manufacturing, 30(12), 1351-1366.

Bitumen, S. (1995). The shell bitumen industrial handbook. Thomas Telford.

Brown, E. R., \& Cross, S. A. (1989). A study of in-place rutting of asphalt pavements (Vol. 58). National Center for Asphalt Technology.

Castañeda, G., Argüello, T., \& Vecchia, F. (2010). Desempeño Térmico de Techo Alternativo para Vivienda en Tuxtla Gutiérrez, Chiapas, México. Revista de La Construcción, 9(1), 81-88.

Chen, J.-S., \& Lin, K.-Y. (2005). Mechanism and behavior of bitumen strength reinforcement using fibers. Journal of Materials Science, 40(1), 87-95

Collis, L., \& Smith, M. R. (1993). Aggregates: sand, gravel and crushed rock aggregates for construction purposes. Geological Society.

Colorado, H. A., \& Loaiza, A. (2017). PORTLAND CEMENT PASTE BLENDED WITH PULVERIZED COCONUT FIBERS. Advances in Materials Science for Environmental and Energy Technologies VI, 262, 79.

Colorado, H. A., Nino, J. C., \& Restrepo, O. (2018). Applications and Opportunities of Nanomaterials in Construction and Infrastructure. In TMS Annual Meeting \& Exhibition (pp. 437-452). Springer.

Davar, A., Tanzadeh, J., \& Fadaee, O. (2017). Experimental evaluation of the basalt fibers and diatomite powder compound on enhanced fatigue life and tensile strength of hot mix asphalt at low temperatures. Construction and Building Materials, 153(Supplement C), 238-246. https://doi.org/https://doi.org/10.1016/j.conbuildmat.2017.06.175

Evans, M. R., Konduru, S., \& Stamps, R. H. (1996). Source variation in physical and chemical properties of coconut coir dust. HortScience, 31(6), 965967.

Fernandes, E. M., Correlo, V. M., Mano, J. F., \& Reis, R. L. (2013). Novel cork-polymer composites reinforced with short natural coconut fibres: Effect of fibre loading and coupling agent addition. Composites Science and Technology, 78, 56-62. https://doi.org/https://doi.org/10.1016/j.compscitech.2013.01.021

Friedrich, K. (2012). Application of fracture mechanics to composite materials (Vol. 6). Elsevier.

GAO, C., \& WU, W. (2017). Using ESEM to Analyze the Microscopic Property of Basalt Fiber Reinforced Asphalt Concrete. International Journal of Pavement Research and Technology. https://doi.org/https://doi.org/10.1016/j.ijprt.2017.09.010

Ge, Z., Wang, H., Zhang, Q., \& Xiong, C. (2015). Glass fiber reinforced asphalt membrane for interlayer bonding between asphalt overlay and concrete pavement. Construction and Building Materials, 101(Part 1), https://doi.org/https://doi.org/10.1016/j.conbuildmat.2015.10.145

Gnedenkov, S. V, Opra, D. P., Zemnukhova, L. A., Sinebryukhov, S. L., Kedrinskii, I. A., Patrusheva, O. V, \& Sergienko, V. I. (2015). Electrochemical performance of Klason lignin as a low-cost cathode-active material for primary lithium battery. Journal of Energy Chemistry, 24 (3), 346-352. https://doi.org/https://doi.org/10.1016/S2095-4956(15)60321-7

Guo, Q., Li, L., Cheng, Y., Jiao, Y., \& Xu, C. (2015). Laboratory evaluation on performance of diatomite and glass fiber compound modified asphalt mixture. Materials \& Design, 66, 51-59. https://doi.org/10.1016/j.matdes.2014.10.033

Hadiwardoyo, S. P. (2013). Evaluation of the addition of short coconut fibers on the characteristics of asphalt mixtures. Civil and Environmental Research, 3(4).

Harish, S., Michael, D. P., Bensely, A., Lal, D. M., \& Rajadurai, A. (2009). Mechanical property evaluation of natural fiber coir composite. Materials Characterization, 60(1), 44-49.

Herráiz, T. R., Herráiz, J. I. R., Domingo, L. M., \& Domingo, F. C. (2016). Posidonia oceanica used as a new natural fibre to enhance the performance of asphalt mixtures. Construction and Building Materials, 102, 601-612.

Huang, Y., Bird, R. N., \& Heidrich, O. (2007). A review of the use of recycled solid waste materials in asphalt pavements. Resources, Conservation and Recycling, 52(1), 58-73.

Huang, Y. H. (1993). Pavement analysis and design.

Jung, D. H., \& Vinson, T. S. (1994). Low-temperature cracking: binder validation.

King, G., King, H., Pavlovich, R. D., Epps, A. L., \& Kandhal, P. (1999). Additives in asphalt. Journal of the Association of Asphalt Paving Technologists, $68,32-69$.

Kumar, G. K., Kumar, B. P., Laxmi, P. V., \& Birru, A. K. (n.d.). A Study on Thermal Conductivity of Hybrid Composite Material with Reinforcement of Coconut Coir.

Lee, S. J., Rust, J. P., Hamouda, H., Kim, Y. R., \& Borden, R. H. (2005). Fatigue cracking resistance of fiber-reinforced asphalt concrete. Textile Research Journal, 75(2), 123-128. 
Li, X., Tabil, L. G., \& Panigrahi, S. (2007). Chemical treatments of natural fiber for use in natural fiber-reinforced composites: a review. Journal of Polymers and the Environment, 15(1), 25-33.

Loaiza, A., Cifuentes, S., \& Colorado, H. A. (2017). Asphalt modified with superfine electric arc furnace steel dust (EAF dust) with high zinc oxide content. Construction and Building Materials, 145, 538-547. https://doi.org/10.1016/j.conbuildmat.2017.04.050

Loaiza, A., Cifuentes, S., \& Colorado, H. A. (2017). Asphalt modified with superfine electric arc furnace steel dust (EAF dust) with high zinc oxide content. Construction and Building Materials, 145. https://doi.org/10.1016/j.conbuildmat.2017.04.050

Loaiza, A., \& Colorado, H. A. (2018). Marshall stability and flow tests for asphalt concrete containing electric arc furnace dust waste with high ZnO contents from the steel making process. Construction and Building Materials, 166, 769-778.

Mallick, R. B., Teto, M. R., \& Mogawer, W. S. (2000). Evaluation of use of manufactured waste asphalt shingles in hot mix asphalt.

Mansourian, A., Razmi, A., \& Razavi, M. (2016). Evaluation of fracture resistance of warm mix asphalt containing jute fibers. Construction and Building Materials, 117(Supplement C), 37-46. https://doi.org/https://doi.org/10.1016/j.conbuildmat.2016.04.128

Marasteanu, M., Clyne, T., McGraw, J., Li, X., \& Velasquez, R. (2005). High-temperature rheological properties of asphalt binders. Transportation Research Record: Journal of the Transportation Research Board, (1901), 52-59.

Matthews, F. L., \& Rawlings, R. D. (1999). Composite materials: engineering and science. Elsevier.

Microstructure, flexural properties and durability of coir fibre reinforced concrete beams externally strengthened with flax FRP composites. (2015). Composites Part B: Engineering, 80, 343-354. https://doi.org/10.1016/J.COMPOSITESB.2015.06.011

Morova, N., Serin, S., Terzi, S., Saltan, M., Ozdemir Kucukcapraz, D., Sargin Karahancer, S., \& Eriskin, E. (2016). Utility of polyparaphenylene terephtalamide fiber in hot mix asphalt as a fiber. Construction and Building Materials, 107(Supplement C), 87-94. https://doi.org/https://doi.org/10.1016/j.conbuildmat.2015.12.193

Neves Monteiro, S., Salgado de Assis, F., Ferreira, C. L., Tonini Simonassi, N., Pondé Weber, R., Souza Oliveira, M., ... Camposo Pereira, A. (2018). Fique Fabric: A Promising Reinforcement for Polymer Composites. Polymers, 10(3), 246.

Ohler, Jg. (1984). Coconut, tree of life.

Pamulapati, Y., Elseifi, M. A., Cooper, S. B., Mohammad, L. N., \& Elbagalati, O. (2017). Evaluation of self-healing of asphalt concrete through induction heating and metallic fibers. Construction and Building Materials, 146(Supplement C), 66-75. https://doi.org/https://doi.org/10.1016/j.conbuildmat.2017.04.064

Panda, M., Suchismita, A., \& Giri, J. (2013). Utilization of Ripe Coconut Fiber in Stone Matrix Asphalt Mixes. International Journal of Transportation Science and Technology, 2(4), 289-302.

Parandoush, P., \& Lin, D. (2017). A review on additive manufacturing of polymer-fiber composites. Composite Structures, 182, 36-53.

Park, P., El-Tawil, S., \& Naaman, A. E. (2017). Pull-out behavior of straight steel fibers from asphalt binder. Construction and Building Materials, 144(Supplement C), 125-137. https://doi.org/https://doi.org/10.1016/j.conbuildmat.2017.03.159

Pfeiffer, J. P. H., \& Van Doormaal, P. M. (1936). The rheological properties of asphaltic bitumens. Journal Institute Petroleum, 22, 414-440.

Poel, V., \& Der, C. (1954). A general system describing the visco-elastic properties of bitumens and its relation to routine test data. Journal of Applied Chemistry, 4(5), 221-236.

Prasad, G. L. E., Gowda, B. S. K., \& Velmurugan, R. (2017). A Study on Impact Strength Characteristics of Coir Polyester Composites. Procedia Engineering, 173, 771-777.

Putman, B. J., \& Amirkhanian, S. N. (2004). Utilization of waste fibers in stone matrix asphalt mixtures. Resources, Conservation and Recycling, 42(3), 265-274.

Radovskiy, B., \& Teltayev, B. (2018). Determining of Asphalt Stiffness Modulus. In Viscoelastic Properties of Asphalts Based on Penetration and Softening Point (pp. 23-39). Springer.

Raghavendra, S. N., Swamy, S. R. R., Rastogi, N. K., Raghavarao, K., Kumar, S., \& Tharanathan, R. N. (2006). Grinding characteristics and hydration properties of coconut residue: a source of dietary fiber. Journal of Food Engineering, 72(3), 281-286.

Read, J., Whiteoak, D., \& Bitumen, S. (2003). The Shell Bitumen Handbook. Thomas Telford. Retrieved from https://books.google.com.co/books?id=bA1tlkRJL8kC

Sani, M. A., Latib, A. A., Ng, C. P., Yusof, M. A., Ahmad, N., \& Rani, M. A. M. (2011). Properties of coir fibre and kenaf fibre modified asphalt mixes. In Proceedings of the Eastern Asia Society for Transportation Studies The 9th International Conference of Eastern Asia Society for Transportation Studies, 2011 (p. 258). Eastern Asia Society for Transportation Studies.

Sengoz, B., \& Oylumluoglu, J. (2013). Utilization of recycled asphalt concrete with different warm mix asphalt additives prepared with different penetration grades bitumen. Construction and Building Materials, 45, 173-183. https://doi.org/10.1016/j.conbuildmat.2013.03.097

Silva, R. V, Spinelli, D., Bose Filho, W. W., Claro Neto, S., Chierice, G. O., \& Tarpani, J. R. (2006). Fracture toughness of natural fibers/castor oil polyurethane composites. Composites Science and Technology, 1328-1335. https://doi.org/https://doi.org/10.1016/j.compscitech.2005.10.012

Su, J.-F., Qiu, J., Schlangen, E., \& Wang, Y.-Y. (2015). Investigation the possibility of a new approach of using microcapsules containing waste cooking oil: In situ rejuvenation for aged bitumen. Construction and Building Materials, 74, 83-92. 
Teles, M. C. A., Altoé, G. R., Amoy Netto, P., Colorado, H., Margem, F. M., \& Monteiro, S. N. (2015). Fique Fiber Tensile Elastic Modulus Dependence with Diameter Using the Weibull Statistical Analysis. Materials Research, 18, 193-199.

Vale, A. C. do, Casagrande, M. D. T., \& Soares, J. B. (2013). Behavior of natural fiber in stone matrix asphalt mixtures using two design methods. Journal of Materials in Civil Engineering, 26(3), 457-465.

van Dam, J. E. G., van den Oever, M. J. A., Teunissen, W., Keijsers, E. R. P., \& Peralta, A. G. (2004). Process for production of high density/high performance binderless boards from whole coconut husk: Part 1: Lignin as intrinsic thermosetting binder resin. Industrial Crops and Products, 19(3), 207-216. https://doi.org/https://doi.org/10.1016/j.indcrop.2003.10.003

Van der Poel, C. (1954). Road asphalt. North-Holland, Amsterdam.

Wambua, P., Ivens, J., \& Verpoest, I. (2003). Composite Science and Technology. Cap, 63, 1259-1264.

Wu, S., Ye, Q., \& Li, N. (2008). Investigation of rheological and fatigue properties of asphalt mixtures containing polyester fibers. Construction and Building Materials, 22(10), 2111-2115. https://doi.org/10.1016/j.conbuildmat.2007.07.018

Yang, J.-M., Kim, J.-K., \& Yoo, D.-Y. (2016). Effects of amorphous metallic fibers on the properties of asphalt concrete. Construction and Building Materials, 128(Supplement C), 176-184. https://doi.org/https://doi.org/10.1016/j.conbuildmat.2016.10.082

Yildirim, Y. (2007). Polymer modified asphalt binders. Construction and Building Materials, 21(1), 66-72.

Zhang, X., Gu, X., Lv, J., Zhu, Z., \& Zou, X. (2017). Numerical analysis of the rheological behaviors of basalt fiber reinforced asphalt mortar using ABAQUS. Construction and Building Materials, 157(Supplement https://doi.org/https://doi.org/10.1016/j.conbuildmat.2017.09.044 